\title{
India Bangladesh Relations: A Study of Issues Influencing the Relations and Recent Trends
}

\section{Javid Ahmad Mir*}

School of Social Sciences, Devi Ahilya Vishwavidyalaya, Indore, India

\begin{abstract}
India's connections with Bangladesh are human advancement, social, social and financial. There is much that joins the two nations-a mutual history and normal legacy, semantic and social ties, energy for music, writing and expressions of the human experience. With Bangladesh, India shares not just a typical history of battle for flexibility and freedom yet in addition continuing sentiments of both friendly and additionally familial ties. This shared trait is reflected in multi-dimensional relations with Bangladesh at a few levels of association. The two countries need to experience an adjustment in outlook, especially at the political level. There is a requirement for more noteworthy comprehension, exchange, discretion, provincial participation and less impedance in each other's interior undertakings. While it might be anything but difficult to just rundown these issues, conquering them would be troublesome, chiefly because of the general geopolitical impulses, the chronicled heritage, and the common question in the locale. This paper will examine some recent trends, as well as explore a possible framework for the future direction of India-Bangladesh relations.
\end{abstract}

Keywords: India; Bangladesh; Issues; Disputes; Recent trends

\section{Introduction}

India and Bangladesh share a common border of $4096 \mathrm{~km}$ running through five Indian states, West Bengal, Assam, Meghalaya, Tripura and Mizoram. India's relations with Bangladesh are traditionally, cultural, social and economic. There is a much that brings them together-a shared history and common heritage, linguistic and cultural ties, passion for music, literature and the arts. India shares not only a common history of struggle for freedom and liberation but also enduring feeling of both fraternal as well as familial ties. This commonality is reflected in the multi-dimensional relations with Bangladesh at several levels of interaction. While India played a critical role in 1971 in the birth of Bangladesh, this does not however result in close bilateral ties. The paper seeks to provide a framework of recent trends in the relations between the two nations. Currently, both nations are enjoying extremely good quality relations.

\section{Theoretical Framework}

The relations between the states are examined through various measuring sticks. The considering measuring sticks are accessible as hypotheses which have been advanced by various scholars who are principally associated with examining and breaking down the relations between countries. The diverse journalists have advanced distinctive speculations to think about the two-sided or multilateral connections. However these speculations are not comprehensive in their implications and can't fit all over the place. These hypotheses are not insusceptible from the constraints and disadvantages but rather what is essential here is the co-connection as a result of which one scientist can go over various upsides and downsides of the two-sided environment between the two neighboring nations, This study concentrates on concentrate the reciprocal relations between the two neighbors i.e. India and Bangladesh and late patterns among the two countries.

\section{Shahnawaz A Mantoo, “India-Bangladesh relationship (1975- 1990)"}

India's connections with Bangladesh are human advancement, social, social and financial, there is much that joins the two nations a mutual history and normal legacy, semantic and social ties, enthusiasm for music, writing and expressions of the human experience. With Bangladesh, India shares not just a typical history of battle for flexibility and freedom yet in addition persisting sentiments of both friendly and familial ties. This shared characteristic is reflected in multi-dimensional relations with Bangladesh at a few levels of collaboration. Be that as it may, there had been many contorts in the past between the two nations especially amid 1975-90, which has been particularly imperative to know [1]. The target of this investigation is to feature the real moves, as there were those huge changes which molded the future course of the connection between the two nations. The examination additionally gives this understanding the national intrigue is the most crucial piece of any nations outside arrangement for which the creator goes to any degree [2].

\section{Research Methodology}

The understudy paper requires the utilization of chronicled and systematic techniques. The authentic procedure has been utilized to feature the chronicled foundation of the issue and after that top to bottom investigation has been made to determine the fundamental contention of the paper. The paper has utilized both critical and in addition secondary information $[3,4]$. The essential sources incorporate strategy archives, outside issue records and other significant essential sources. The secondary sources which have been utilized as a part of the paper constitute of books, papers and other important optional material. Actually the information has been utilized from the two sources and thus an endeavor has been made to reach the sensible conclusion.

*Corresponding author: Javid Ahmad Mir, Research Scholar at School of Social Sciences, Devi Ahilya Vishwavidyalaya, Indore, India, Tel: +0731 252 7532; E-mail: mirjavid41@gmail.com

Received December 06, 2017; Accepted December 29, 2017; Published January 05, 2018

Citation: Mir JA (2018) India Bangladesh Relations: A Study of Issues Influencing the Relations and Recent Trends. Arts Social Sci J 9: 322. doi: 10.4172/2151. 6200.1000322

Copyright: (c) 2018 Mir JA. This is an open-access article distributed under the terms of the Creative Commons Attribution License, which permits unrestricted use, distribution, and reproduction in any medium, provided the original author and source are credited. 


\section{Issues Influencing Relations}

\section{Water debate}

India and Bangladesh share 54 trans-limit streams, of all shapes and sizes. In 1996, the sharing of the Ganga waters was effectively settled upon between the two countries. In any case, the real zone of debate has been India's development and operation of the Farakka Flood. The point of development of the Farakka Flood was to expand the lean time frame stream of the Bhagirathi-Hooghly branch of Ganga to build the water profundity at the Kolkota port which was undermined by siltation. As water system withdrawals expanded in Bangladesh, question emerged amongst India and Bangladesh over the sharing of the lean season stream at Farakka. The insufficiency of water amid the lean season to meet the evaluated requests in the two nations is the underlying driver of the contention [5].

The Bangladesh government feels that the decrease in stream made harm agribusiness, industry and nature in the bowl in Bangladesh. Due to the powerlessness of the concerned governments to go to any enduring assention in the course of the most recent couple of decades on sharing the stream water, this issue has developed and now it is additionally seen as an instance of upstream-downstream debate. The other explanation behind water debate is Teesta Stream - which has its source in Sikkim - moves through the northern piece of West Bengal in India before entering Bangladesh, where subsequent to intersection through around $45 \mathrm{~km}$ of irrigable land, converges with the Brahmaputra Waterway (or Jamuna when it enters Bangladesh). In 1983, a specially appointed water sharing assention was come to amongst India and Bangladesh, whereby the two nations were distributed 39\% and $36 \%$ of the water stream separately. The new respective arrangement develops this understanding by proposing an equivalent designation of the Teesta Stream. Be that as it may, the arrangement fell through when the then recently chose Boss Clergyman of West Bengal, Ms. Mamata Banerjee, declined to affirm the arrangement, expecting that the loss of higher volume of water to the lower riparian would cause issues in the northern area of state, particularly amid drier months. Development of the Tipaimukh Dam is another petulant issue amongst India and Bangladesh. Tipaimukh Dam is a hydel control venture proposed on the waterway Barak in Manipur. Bangladesh's protest is that it would have unfriendly natural impacts in its eastern Sylhet region. Notwithstanding India's emphasis that no dam would be built disregarding Bangladesh's protests, the contention is a long way from being done.

The famous contentions in Bangladesh against the Tipaimukh venture are: (an) India ought not to choose what is useful for individuals of Bangladesh without taking them into certainty. (b) No think about has been attempted in Bangladesh to evaluate the effect of the environments that exist and rely upon the characteristic stream of the water in Surma Kusiyara-Meghna and their tributaries. India and Bangladesh have concurred on a joint report gathering to look at the focuses raised by Bangladesh.

\section{Insurgence}

India's north-eastern states, as announced in the press, are tormented by rebellion. It is accepted there are around 175 radical gatherings working in the states encompassing Bangladesh. Bangladesh itself has been battling a revolt throughout the previous couple of decades in its south-eastern part called Chittagong Slope Tracts, despite the fact that it has been enormously contained as far back as the marking of the peace accord with the extremists in 1997.
It is likely that there could be an overflow impact of radicals taking sanctuary in each other's nation or utilizing cross-outskirt courses for the transportation of snuck arms. One Indian source asserts "another arms bazaar in the dead zone close to the Bangladesh-Myanmar border town of Naikhangchari, which has turned out to be home to Indian radical outfits, for example, the Unified Freedom Front of Assam and the National Majority rule Front of Bodoland. The Harkat-ul-Jihad-alIslami, a fear based oppressor furnish in Bangladesh, is known to grant preparing to these outfits".

In a current meeting, the head of the fringe security powers traded arrangements of the "culprits" (Bangladesh and India indicating 1,227 and 77 "offenders" individually) covering up in their separate nations. Actually, cross-outskirt fear based oppression, in various structures and indications, is a reality in the entire of South Asia. Revolt in northeast India had ended up being an Achilles' foot rear area for even the English Raj, which neglected to set up its suzerainty over these insurrection inclined regions. Cross-outskirt psychological warfare or insurrections convey possibilities for fire.

\section{Transit issue}

Keeping in mind the end goal to handle the revolt all the more viably and exhaustively, India, for clear geopolitical reasons, needs an immediate course through Bangladesh that would facilitate the In any case, another school of thought opines that Bangladesh would receive awesome budgetary rewards from the travel and along these lines diminish the exchange hole that exists between the two nations. There is a likelihood that India, consequently, would be additionally expected in settling different issues like water sharing, arrive and oceanic fringe outlines, and the lifting the non-levy hindrances that India forces on the merchandise imported from Bangladesh. This is induced in light of the fact that so far there has not been any generous advance in settling the greater part of the major exceptional issues. This creator feels that such improvements would help make a compensation situation. Be that as it may, given the sensitivities and doubts included, it might be hard to achieve this coveted state within a reasonable time-frame [6].

\section{Maritime boundary demarcation}

Another combative issue amongst India and Bangladesh that has as of late gone under the spotlight is the sea fringe division, an issue that additionally includes Myanmar. The Sound of Bengal, found south of Bangladesh, could be the nation's new outskirts for assets. Bangladesh guarantees an enormous mainland rack, since the ocean isn't impressively profound as observed from its benchmark. Bangladesh is stressed that it may get ocean or zone-bolted by the two India and Myanmar if the two forces demand settling the issue in light of the rule of equidistance rather than value. There are dubious issues, for example, the acknowledgment of a Bangladeshi gauge, and the obsession of control focuses with its neighboring countries from where both of these neighbors would draw the sea limit. Connected to it is the argument about the responsibility for island in the Stream Hariabhanga, in the south-western piece of Bangladesh, flanking India, and bordering the Straight of Bengal. Settling the issue of South Talpatty/New Moore (the names, separately, that the island is given by Bangladesh and India) has "more to do with the degree of the sea zone to be conceivably obtained in the oil rich delta of the Cove of Bengal than the island itself. Accordingly the island holds the possibility to wind up plainly the center combative issue between the two countries." The Hindu of India reports that India-Bangladesh sea limit talks stay uncertain. The question were basically finished the Talpatty/New Moore Island and the claim on selective monetary zones in the Narrows of Bengal. 
Thus the issue may must be alluded to the Indeed Bangladesh has as of late disagreed with the Assembled Countries for assertion. Keeping the issue uncertain would keep on vitiating the relations with spiraling questions. There is, be that as it may, a case of the Worldwide Court giving a model decision for value rule, considering the area of the two neighboring nations and form of the shoreline $[7,8]$.

\section{Recent Trends in India Bangladesh Relations}

As Sheik Hasina took on the position of Executive in 2009, the twosided connection amongst Dhaka and New Delhi was changed. Once chose again with a more grounded order, she rapidly start changing the Bangladesh-India relationship in what has been named an "IndiaPositive" approach. Executive of Bangladesh Ms. Sheik Hasina joined by a 123-part appointment including a business landmass paid a state visit to India. At this summit, the two sides consented to construct an "irreversible" agreeable connection between the two neighbors. On her visit, PM Sheik Hasina was given the esteemed Indira Gandhi Prize for Peace, Demilitarization and Advancement for 2009.

Amid Hasina's visit to India, the then Finance Minister Pranab Mukherjee marked a $\$ 1$ billion advance manage the Hasina government, the biggest credit extension got by Bangladesh under a solitary assention. India's Exim Bank consented to the arrangement with Bangladesh's financial relations division and the advance was be utilized to create railroads and interchanges foundation in Bangladesh. The arrangement conveyed a 1.75 percent yearly loan fee and would be repayable in 20 years, including a five-year effortlessness period. India and Bangladesh marked 3 agreements on a) common legitimate help with criminal issues, b) fighting universal fear based oppression, sorted out wrongdoing and illegal medication trafficking; and c) exchange of condemned individual amid the Hasina's visit. It was likewise concurred that Bangladesh will permit utilization of Mongla and Chittagong Ocean ports for development of merchandise to and from India through street and rail. Bangladesh additionally passed on its aim to give Nepal and Bhutan access to these ports. This was trailed by the two nations marking a 35-year power transmission bargain under which India will send out up to 500 megawatts of energy to Bangladesh. Dhaka likewise marked a $\$ 1.7$ billion agreement with the National Warm Power Enterprise for the development of two coal-let go plants in southern Bangladesh. Bangladesh consented to give travel office to India to access its landlocked 7 north-Eastern States through Bangladesh. Enhanced rail connections would profit both Bangladesh and India's eastern locale. Not just trucks from Nepal would approach the Bagla bandha arrive port in Bangladesh; Bangladeshi trucks would likewise approach Nepal through India. Dhaka had given its assent for laying the cross-limit rail tracks. In spite of these activities, India neglected to expand on the force furnished by Hasina's visit with its inability to execute two noteworthy two-sided understandings: a conclusion of land limit boundary and the sharing of the waters of the Teesta Stream.

Political issues between the two states have secured all fields of arrangement, from monetary and exchange, outskirt security and limit lines, sharing of normal and trans-limit waters, correspondence and travel, lastly, local and national security against extremist systems. Advance on a considerable lot of these issues was slowed down from 1975 until 2009; be that as it may, changes in the reciprocal relations have as of late prompted impressive development on all issues of conflict. Amid the previous couple of years, Sheik Hasina's Administration has enough tended to India's security related worries; there has been a recognition in Bangladesh that Bangladesh has not been remunerated satisfactorily consequently. From November 2013, A Wagah Fringe like service is being sorted out at Petrapole (in West Bengal, India) - Benapole (Bangladesh) outskirt checkpoint. The service which incorporates parades, walk past and bringing down of the national banner of both the nations is currently an everyday schedule, at twilight, on the eastern outskirt. The relations between the nations are unquestionably moving positive way. Indian External Affairs Minister Sushma Swaraj went to Bangladesh in her first authority abroad excursion in June, 2014. On 7 May 2015 the Indian Parliament, within the sight of Bangladeshi representatives, consistently passed the Land Limit Understanding (LBA) as its 100th Protected revision, in this way settling every one of the 68-year old fringe question since the finish of the English Raj. The bill was pending sanction since the 1974 Mujib-Indira concurs. In June 2014, amid her first authority abroad visit, Sushma Swaraj closed different understandings to support ties. They include:

- Easing of Visa administration to give 5 year numerous passage visas to minors beneath 13 and elderly over 65 .

- Proposal of an exceptional monetary zone in Bangladesh.

- Agreement to send back a criminal blamed for kill in India.

- Provide an extra $100 \mathrm{MW}$ control from Tripura.

- Increase the recurrence of Maitree Express and begin transports amongst Dhaka and Guwahati and Shillong.

- Bangladesh enabled India to ship sustenance and grains to the landlocked Upper east India are utilizing its domain and foundation.

In any case, course has changed after the difference in government in India, which advocates a solid 'neighborhood first' outside approach. It is against this short scenery that our Prime Minister Modi embraced an official visit to Bangladesh (June 6-7, 2015). The significance of Bangladesh as an accomplice for India's development was clear when Modi picked Bangladesh as the goal of his Clergyman of outside Issues' first remote visit. Amid Sheik Hasina's four-day visit to New Delhi in April2017, Bangladesh and India consented to two barrier arrangements, the principal such assertions amongst India and any of its neighbors. Under the understandings, the militaries of the two nations will direct joint activities and preparing. India will enable Bangladesh to set up assembling and administration places for protection stages that the two nations have with the point of accomplishing independence in safeguard fabricating in Bangladesh, and will likewise furnish the Bangladesh military with master preparing, and specialized and calculated help. India likewise broadened its first since forever safeguard related credit extension to a neighboring nation, by furnishing Bangladesh with $\$ 500$ million to buy guard hardware. Bangladesh marked a 4.5 billion dollar credit manage India in 4 October 2017 for building up its foundation, wellbeing and instruction. The understanding was marked in Dhaka within the sight of Indian Back Clergyman Mr. Arun Jaitley and his Bangladesh partner A.M.A Muhith. Bangladesh will utilize the assets for 17 need framework ventures, which incorporate power, railroads, streets, sending and ports.

\section{Notun projonmo-nayi disha (new beginning-new direction)}

Prime Minister Narendra Modi's fruitful two-day visit to Dhaka (June 6-7 2015) saw the marking of a huge number of 22 understandings covering the whole extent of political, monetary and social relations. Among these assention, five issues that are a piece of the 60-point Notice of Comprehension (MOU) emerge and guarantee a period 
of more prominent helpful relationship, best reflected in the title of the joint revelation - Notun Projonmo-Nayi Disha (Fresh start New Bearing). These understandings are identified with network - a need region for the Narendra Modi Government - and incorporate lattice interconnection and age of energy, enhancing the adjust of exchange, better coordination among the fringe guarding powers and individuals to-individuals contact. While the initial two issues are to be progressed inside a sub-local system, different issues are solely reciprocal in nature. Be that as it may, in a noteworthy advance towards ties, India and Bangladesh traded the instruments of approval of the Land Limit Assention, Promising a conclusion to the "stateless presence" of more than 50,000 individuals in 162 enclaves on the two sides of the outskirt.

\section{Conclusion}

More prominent local collaboration, particularly in the field of financial improvement to destroy the neediness trap, might be a definitive objective of every single South Asian. Be that as it may, unless some remedial and brilliant measures are embraced right now, the circumstance may move the other way. That would be amazingly unsettling for the large number of destitution stricken South Asians. They may need to go past the geopolitical impulses and move towards more concrete provincial collaboration like what the Europeans and Southeast Asians are doing. Something else, improvement as such will just evade the South Asians. Lastly, the MOU emphasized the significance of people to people contact in carrying the relationship forward, not only the two bus services were flagged off and more bus and train services were agreed upon, India and Bangladesh also announced the opening of new consulates in Sylhet and Khulna for India and in Guwahati for Bangladesh, Similarly since the Dhaka Kolkata Mitree Express is currently very popular and India has also agreed to construct a modern international passenger terminal to mitigate the grievances of travelers between the two cities. The two nations likewise have huge interests in proceeding to work together in battling fear based oppression. In the event that India will expand its control over its immature upper east, financial network and improved combination with other territorial on-screen characters like Bangladesh, Bhutan, and China is basic. India will have a significantly more noteworthy shot of achievement at keeping up peace in its northeastern states while creating them financially with Bangladesh's proceeded with collaboration, however Bangladesh likewise has a solid motivating force to help India. Precariousness along the fringe areas of Bangladesh can serve to stop Indian venture, as well as indications of instability may likewise take away from other advancement and undermine the possibilities of Bangladesh turning into a local center point.

\section{References}

1. Mantoo SA (2015) India-Bangladesh Relationship (1975-1990). Journal of South Asian Studies 3: 331-349.

2. Abass BM (1982) "The Ganga Water Dispute" Vikas Publishing House New Delhi.

3. Emjuddin A, Nazneen DRJA (1990) Islam in Bangladesh: Revivalism or Power Politics? Asian Survey 30: 795-808

4. Raja Mohan C (2004) Cooperative Security in South Asia. South Asia Journal.

5. Singh J (1996) National Security An Outline of Our Concerns. Lancer Publishers New Delhi in association with United Services Institutions of India, pp: 59-60.

6. Karim MA (2009) Bangladesh-India Relations: Some Recent Trends, ISAS Working Paper.

7. Arora ND (2016) Political Science Textbook. Mc Graw Hill Publication Pvt Ltd New Delhi.

8. Bhardwaj S (2008) India-Bangladesh Relations: Are the carrots working? Institute of Peace and Conflict Studies New Delhi. 